\title{
South-Siberian mountain mires: Perspectives on a potentially vulnerable remote source of biodiversity
}

\author{
Irina I. Volkova $\mathbb{1}$, Terry V. Callaghan, Igor V. Volkov, \\ Natalia A. Chernova, Anastasia I. Volkova
}

Received: 17 February 2021/Revised: 2 June 2021/Accepted: 17 June 2021/Published online: 9 July 2021

\begin{abstract}
Changes in climate, land-use and pollution are having disproportionate impacts on ecosystems and biodiversity of arctic and mountain ecosystems. While these impacts are well-documented for many areas of the Arctic and alpine regions, some isolated and inaccessible mountain areas are poorly studied. Furthermore, even in well-studied regions, assessments of biodiversity and species responses to environmental change are biased towards vascular plants and cryptogams, particularly bryophytes are far less represented. This paper aims to document the environments of the remote and inaccessible Altai-Sayan mountain mires and particularly their bryofloras where threatened species exist and species new to the regional flora are still being found. As these mountain mires are relatively inaccessible, changes in drivers of change and their ecosystem and biodiversity impacts have not been monitored. However, the remoteness of the mires has so far protected them and their species. In this study, we describe the mires, their bryophyte species and the expected impacts of environmental stressors to bring attention to the urgency of documenting change and conserving these pristine ecosystems.
\end{abstract}

Keywords Biodiversity · Bryophytes · Climate change · Mountain mires $\cdot$ Siberia

In memory of Emelian Muldiyarov, Siberian bryologist, mire scientist, teacher and friend.

Supplementary Information The online version contains supplementary material available at https://doi.org/10.1007/s13280021-01596-w.

\section{INTRODUCTION}

Changes in natural ecosystems have become unusually pronounced in recent decades. These changes are associated not only with a trend of warming climate (Kirpotin et al. 2009; Seneviratne et al. 2012; Golitsyn and Vasiliev 2019), but also with an increased climate instability, namely in the frequency of catastrophic climate-induced events such as droughts, fires, floods, rain-on-snow events and heat waves (Bokhorst et al. 2009; Sokolov et al. 2016). Climate changes interact with developing land-use practices that lead to a range of consequences ranging from abandonment of agricultural land to intensification of resource extraction such as in the gas and oil industries (Kirpotin et al. 2021).

Climate change is impacting the environment and vegetation in Siberia and in the Russian part of the Altai-Sayan region. Over the period of instrumental satellite observations (1996-2014), Ponomarev et al. (2016) reported that a logarithmic growth in the number of burnt areas and fire frequency was found for forest, steppe, and forest steppe zones as in other parts of Siberia. The current climate warming observed in southern Siberia is most evident in the alpine zone of the Altai and Sayan Mountains (Kharlamova et al. 2019) and is leading to aridification of the mountain steppes, altitudinal tree-line migration and restructuring of mountain biotopes (Chlachula 2005). The climate is predicted to become much drier than today in the southern part of the Altai-Sayan mountains, resulting in drastically decreasing extents of mountain biomes including alpine, alpine tundra, and subalpine plant communities (Kokorin 2011).

In addition to long term warming trends, heat waves in Siberia are becoming more intensive and frequent (Fig. 1A; Russo et al. 2015; Harris 2018) as in the 

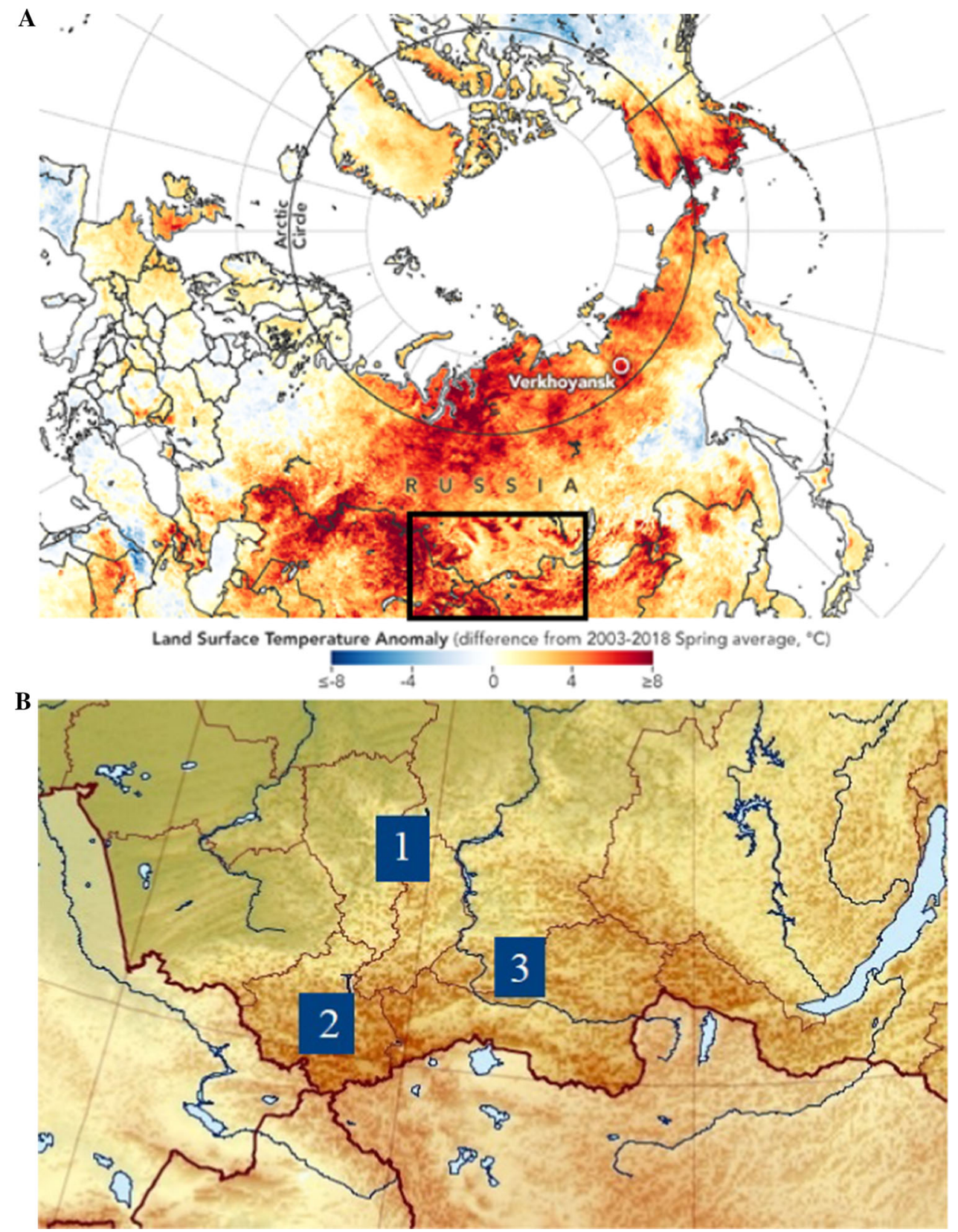

Fig. 1 A Long-lasting heat waves in Siberia (NASA Earth Observatory, March 19-June 20, 2020) (Voiland 2020). These cause fires and thaw permafrost. They are followed by extra carbon emissions and contribute to the greenhouse effect. B Locations of survey regions: (1) the Kuznetsky Alatau range (northern SR1), (2) several ranges within the Russian Altai Mountains (south-west SR2), (3) the Ergaki range of the West Sayan Mountains (south-east SR3). At the right is Lake Baikal

Northern Hemisphere in general (e.g. Russo et al. 2014). However, magnitudes and duration of temperature anomalies are dependent on latitude: although Arctic temperatures rise more rapidly than the global mean, the occurrence of heat waves in summer in the middle and low latitudes may be even more frequent than in the cryolithozone where additional heat is partly used for the accelerated melting of sea-ice and thawing of permafrost (Dobricic et al. 2020).
Mountain areas are especially sensitive to climate change (IPCC 2014) as the high heterogeneity of abiotic conditions over short spatial scales is reflected in the elevational variation of the diversity and composition of many montane plant and animal communities. This results in especially high levels of diversity and endemism where mountain systems are geographically separated (Körner 2004). The sensitivity of mountain regions to change is particularly important as they provide many ecosystem 
services such as water supply for the lowlands and habitats for specific floras and faunas. Where the mountains are isolated, they are also important refugia for endemic species.

The azonal (not restricted to any climate zone) situation of the mountains allows us to consider them as indicators of change in various climatic zones (Rogora et al. 2018). The relative compression of altitudinal zones in mountains compared with latitudinal zones (Zhenlin et al. 2012) makes them more sensitive to climate changes than lowland ecosystems while lower intensity of land use than in the lowlands makes impacts of climate change more evident as intensive land use can mask natural changes. It is believed that climate change will primarily cause the disappearance of populations and species in the ecosystems of the upper mountain zones (Hanski 2015) and biodiversity changes have been recorded on many mountain tops (Steinbauer et al. 2018). However, at present, we know relatively little about the dynamics of processes occurring in the high mountains of central Eurasia. Furthermore, most studies of biodiversity changes in the mountain regions focus on vascular plants and usually neglect bryophytes and lichens and wetland communities such as those of mountain mires. This applies particularly to isolated, remote and inaccessible mountain regions.

Although mires are considered as ecosystems with a high degree of self-organization and autonomy (Ivanov 1975; Joosten 1993), shallow and small sized mountain mires are expected to have less resilience to environmental changes than the huge mires of the lowland plains, such as the Great Vasyugan Mire (Kirpotin et al. 2021). Within the mountains, the mire habitats are an additional and specific refuge for often rare and threatened hygrophilous species (Volkova et al. 2009) and conserve an important component of mountain biodiversity.

Bryophytes play a special role in the formation of mires as they are the key components, or ecosystem engineers (i.e. edificators (Poplavskaya 1924)). These are plant species having a clearly defined habitat-formation ability, that is, the ability to determine the structure and, to a certain extent, the species composition of a phytocoenosis (i.e. plant community), or such as those of mire and peatland ecosystems. Sphagnum mosses play this important role most significantly (e.g. Clymo and Hayward 1982; Succow and Joosten 2001). Those bryophytes such as Sphagnum with ectohydric characteristics, are very sensitive to water regime in their habitats (Fig. 2). This makes them more convenient indicators of the hydrological state of mires compared to higher plants (Botch 1972; Elina et al. 1984). Also, as bryophytes reflect the surrounding surface water chemistry and they show various sensitivities among species, they are good indicators of $\mathrm{pH}$, electrical conductivity

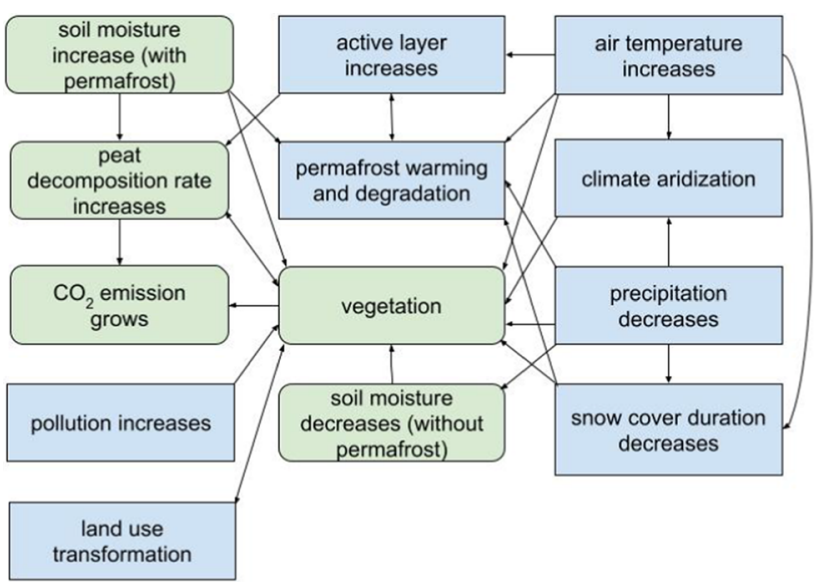

Fig. 2 Feedbacks between drivers and effects on the South-Siberian mountain mires referred to in the text (blue rectangles-drivers; green rectangles with rounded corners-changing ecosystem components)

and calcium concentration etc. (Bengtsson et al. 2016) as well as recording the deposition of pollutants (e.g. Pitcairn et al. 2006; Volkova et al. 2010; Vergel et al. 2020) (Fig. 2). Although some Sphagnum mosses are more resistant to climate change than others (Lang et al. 2012), some Sphagnum species appear more sensitive to climatic conditions, with higher precipitation favoring fastergrowing species (Fig. 2. Moreover, the species composition of bryophytes may indicate the stage of mire development, pointing the direction/stage of a mire ecosystem's dynamics (Bragazza 2006). The slow decomposition of species such as Sphagnum leads to peat accumulation that preserves records of human activities and climatic fluctuations of the past Holocene period (e.g. Joosten and Clarke 2002; Parish et al. 2008).

To understand the structure and functioning of the central Eurasian mountain ecosystems during environmental change, it is necessary to study their basic characteristics and conduct an initial inventory of biodiversity including the diversity of the mire-forming bryophyte component, particularly Sphagna. Critical reviews of certain sections of the genus Sphagnum conducted in Russia have led to a significant increase in species diversity there-from 43 Sphagnum species in 2000 to 56 species in 2015 (Maksimov 2015) — and new records are still being made (e.g. Volkova et al. 2009; Lapshina and Maksimov 2014). Despite this, the study of Bryophyta, in particular Sphagnaceae, significantly lags behind the study of the flora of vascular plants, and very few field studies include bryophytes at the species level (Lett et al. in review). Studies of bryophyte diversity of the rare, unique and often inaccessible mountain mires in Siberia are therefore required from the perspectives of understanding the dynamics of the ecosystem, its biodiversity and vulnerability to change and potential loss of its special bryoflora. 
Our main aim in this paper is to hypothesize how environmental changes could influence the mountain mire ecosystems in the center of the Eurasian Continent (Fig. 2), and particularly the diversity, abundance and distribution of bryophytes. Also, we aim to make the global community more aware of Russian data on remote regions and an under-studied group of plants. We focus on mountain mires and their bryophytes in the remote and generally inaccessible Altai-Sayan Mountains, in the center of the Eurasian continent. Due to their inaccessibility, monitoring changes in environment and biodiversity has not been possible. Consequently, we describe the mires and their biodiversity as well as environmental changes as a current base-line against which future changes can be documented and management interventions implemented. Our study contributes to a wider study on Siberian Environmental Change (Callaghan et al. 2021).

\section{FOCAL SITES}

The three regions chosen for the field research are the most paludified territories within the Altai-Sayan mountains (Fig. 1B). The distance between these survey regions (SR) is between 400 and $500 \mathrm{~km}$.

The Altai-Sayan Mountains stretch over four countries: Russia, China, Mongolia and Kazakhstan. They are the highest mountains in Northern Asia with Belukha Mountain reaching $4509 \mathrm{~m}$ a.s.l. Within Russian borders, the Altai-Sayan Mountains represent the southern part of West and Central Siberia and cover about $700000 \mathrm{~km}^{2}$. The Kuznetsky Alatau range (SR 1) stretches from north to south for $300 \mathrm{~km}$, with a maximum width of $150 \mathrm{~km}$. The Altai mountain area (SR 2) is about $150000 \mathrm{~km}^{2}$. The West Sayan Mountains (SR 3) are an elongated east-west mountain range system of $650 \mathrm{~km}$ length and $200 \mathrm{~km}$ width. Being situated in the center of the continent, the Altai-Sayan mountains are located at the southern border of the cryolithozone of Siberia, namely, the subzone of discontinuous permafrost. The permafrost patches are found depending on altitude, slope exposition, geomorphological elements, type of soil and vegetation (Zheleznyak et al. 2020), but the permafrost in peatlands south of the permafrost limit can be considered as a special case (Brown 1967).

On average, the climate of the Altai-Sayan Mountain area is sharply continental with very cold winters (from -7 to $-34{ }^{\circ} \mathrm{C}$ in various areas, with extremes up to -58 ${ }^{\circ} \mathrm{C}$ ) and cool summers (5 to $19^{\circ} \mathrm{C}$, sometimes $40^{\circ} \mathrm{C}$ ) (Kharlamova and Ostanin 2012). Climate formation is significantly influenced by the western transition of air masses, which determine the precipitation. The Altai mountain area and the Kuznetsky Alatau range in the western part of the mountain area are more influenced by western wet air masses and are more distant from the center of the Asian anticyclone than the Sayan Mountains. Consequently, the climate of the survey regions varies from hyper-humid in the central watershead and on the western macro-slope of the Kuznetsky Alatau range (where precipitation occurs mainly in the form of snow and reaches $3000 \mathrm{~mm}$ per year, with extremes up to $10000 \mathrm{~mm}$ per year (Shpin 1980)) to arid in the South-Eastern Altai Mountains (only $120 \mathrm{~mm}$ per year).

The research was performed partly in protected territories (Fig. 1B): SR 1-Kuznetsky Alatau Nature Reserve $\left(\mathrm{N} 53^{\circ} 45^{\prime} 00^{\prime \prime} \mathrm{E} 89^{\circ} 15^{\prime} 00^{\prime \prime}\right)$, SR 2-Katunsky Nature Bio-

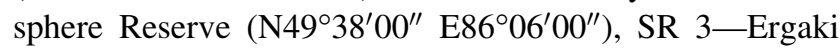
Nature Park $\left(\mathrm{N} 52^{\circ} 50^{\prime} 00^{\prime \prime} \mathrm{E} 93^{\circ} 21^{\prime} 00^{\prime \prime}\right)$. Three mire massifs are situated close to the INTERACT Aktru Research Station (https://eu-interact.org/field-sites/aktru-researchstation/) and are included in the environmental monitoring program of the station. (A mire massif is the entire mire/peatland within the enclosed continuous border of a peat deposit (Peat dictionary 1984)).

\section{Recording biodiversity}

Our research is based on an integrated landscape-ecological approach, which is traditional for Russian mire science (e.g. Sukachev 1915). This approach includes complex investigations of such mire features as position in the landscape, hydrological regime, flora, vegetation, peat stratigraphy and spatial heterogeneity at various levels (which is a specific feature of most mire massifs).

Study sites were selected based on a thorough analysis of literature (scientific papers, research reports, official state reports of nature reserves, government ecological departments), cartographic materials and satellite images. We included in our ground observations the territories where we expected to find the maximum number of mire massifs and the largest mires. The region surveyed is unique in its size - the Altai-Sayan Mountains cover more than 1 million square kilometers (four times larger than Great Britain), and we visited 12 mountain ranges and 3 intermountain depressions within this territory. The mire massifs we identified represent the entire range of variety of landscape units, relief, anthropogenic impact and types of vegetation in completely different climatic conditions (for example, annual precipitation varies from $50 \mathrm{~mm}$ to several thousand $\mathrm{mm}$ ). Previous similar research in this region is absent.

Since 1996, we have investigated a total of 210 mountain mire massifs with an area of $4 \mathrm{~m}^{2}$ to $100 \mathrm{~km}^{2}$, situated along a hyper-humid to arid gradient within the AltaiSayan region in the south of West Siberia. Some mire massifs were visited twice or more, and vegetation 
described at the same relevés (using GPS coordinates) with an interval of 15 years that allowed visual monitoring of the overall dynamics of the ecosystems. However, most of the mires, with GPS coordinates taken, were visited only once because of difficult access.

The vegetation surveys were conducted according to Mueller-Dombois and Ellenberg (1974) and Kuznetsov (1991). Geobotanical descriptions (relevés) of mire sites (more than 1800 descriptions) were prepared for each type of mire habitat (separate mire massifs contain one to about ten types of habitat). The relevés ranged from 4 to $2500 \mathrm{~m}^{2}$ depending on the type of vegetation: mossy mire vegetation requires less area to describe than forested areas. In the case of complex mire vegetation (for example, hummock-hollow or ridge-lake), the descriptions were prepared separately for the various elements of the complex. Four to ten relevés were randomly located within each type of habitat of each mire. Each relevés location is fixed by GPS.

The species' cover/abundance $\mathrm{n}$ and analysis of the relevés followed the Braun-Blanquet school's methodology (Braun-Blanquet 1964). The list of the bryophyte species resulting from all the relevés was used to analyse the taxonomical structure of the bryoflora. The cover/abundance of each species within a relevé was visually estimated using a modified Braun-Blanquet's scale (class 2 (6-25\%) was divided into $2 \mathrm{a}$ and $2 \mathrm{~b}$ ). The scale of cover classes is: $r$-only one specimen; +-0 to $1 \% ; 1$ to $2-5 \% ; 2 \mathrm{a}-6$ to $12 \% ; 2 \mathrm{~b}-13$ to $25 \% ; 3-26$ to $50 \% ; 4-51$ to $75 \% ; 5-76$ to $100 \%$. Further processing of the relevés was made using Braun-Blanquet's synthesis table technique. As a result, a preliminary ordination of plant communities was conducted and the mire vegetation classification was completed.

The initial geobotanical material is partially (245 relevés) entered into the "Database of Siberian Vegetation (DSV)" computer database of relevés of Siberian vegetation, registered in the international metadatabase "Global Index of Vegetation-Plot Databases" as ASRU-002 and included in the integrated botanical information system IBIS v.7.2 (Zverev 2007).

The list of the bryophyte species resulting from all the relevés was used to analyse the taxonomical structure of the bryoflora. New findings of the mosses and hepatics on the mires of the Altai-Sayan Mountains were checked according to previous research (for example, Ignatov 1994). The list includes not only territorial affiliation of the mire bryophytes, but also visually observed characteristics of the loyalty to mire habitats. On the basis of the loyalty to mire habitats ("exclusiveness"), all bryophyte species recorded on the mires were divided into groups: from Vobligate helophytes-to I-accidental species (Appendix S3, Tables S5, S6). The first two groups of species demonstrating the highest fidelity to mires, are together actually called the mire flora, or "the core of the mire flora," or "mire florocoenotic complex" (Yurtsev and Petrovsky 1971). The "core mire flora" concept explained in Suplementary Material Appendix S2.

The mire bryofloras of the three study regions together represent a partial flora of mountain mires of the south of Siberia. (The term and concept of a partial flora as a complex of species of separate ecotope type (in our casemire habitats) within the total flora of some region is proposed by Yurtsev (1982)). The floristic relationships among the three geographically isolated bryofloras were expressed by means of Sørensen's index of similarity to determine homogeneity and $\beta$-diversity.

In total, we have collected and identified more than 15000 samples of mire bryophytes. Most of the collection is kept at Tomsk State University, Russia. Names and nomenclature of species and other taxa for mosses are given according to the "Check-list of mosses of East Europe and North Asia" by Ignatov et al. (2006); for liverworts-according to the "Liverworts and hornworts of Russia” by Potemkin and Sofronova (2009).

Although little quantitative data is available on anthropogenic and climatic changes and their impacts on the mires, we gathered qualitative information as a context for possible changes in the mires and their bryofloras and to identify needs for future quantitative monitoring.

\section{Potential main drivers of changes in the mountain environment of South Siberia (Altai-Sayan Mountains)}

We propose a conceptual framework to describe the main current and future drivers of the possible changes in the South-Siberian mountain mire ecosystems (Fig. 2).

\section{Recent climate changes}

The most dramatic changes of climate are recorded for the Altai Mountains (SR 2), the most arid site of the three investigated, especially in the south-east at the border with the drylands of Mongolia (Fig. 3A). Average annual air temperature at four state meteorological stations in the Altai Mountains, increased by about $2{ }^{\circ} \mathrm{C}$ between 1932 and 2012 (Bezuglova et al. 2012) although there was a slight cooling during the last decade, as well as the absence of significant changes in the precipitation regime. This indicates a clear trend of increasing aridization of the territory, since the observed increase in air temperature is not accompanied by a corresponding increase in precipitation (Sukhova and Zhuravleva 2017). The increase in temperature is much higher in winter and spring than in summer and autumn (Bourgeois et al. 2000). 
A
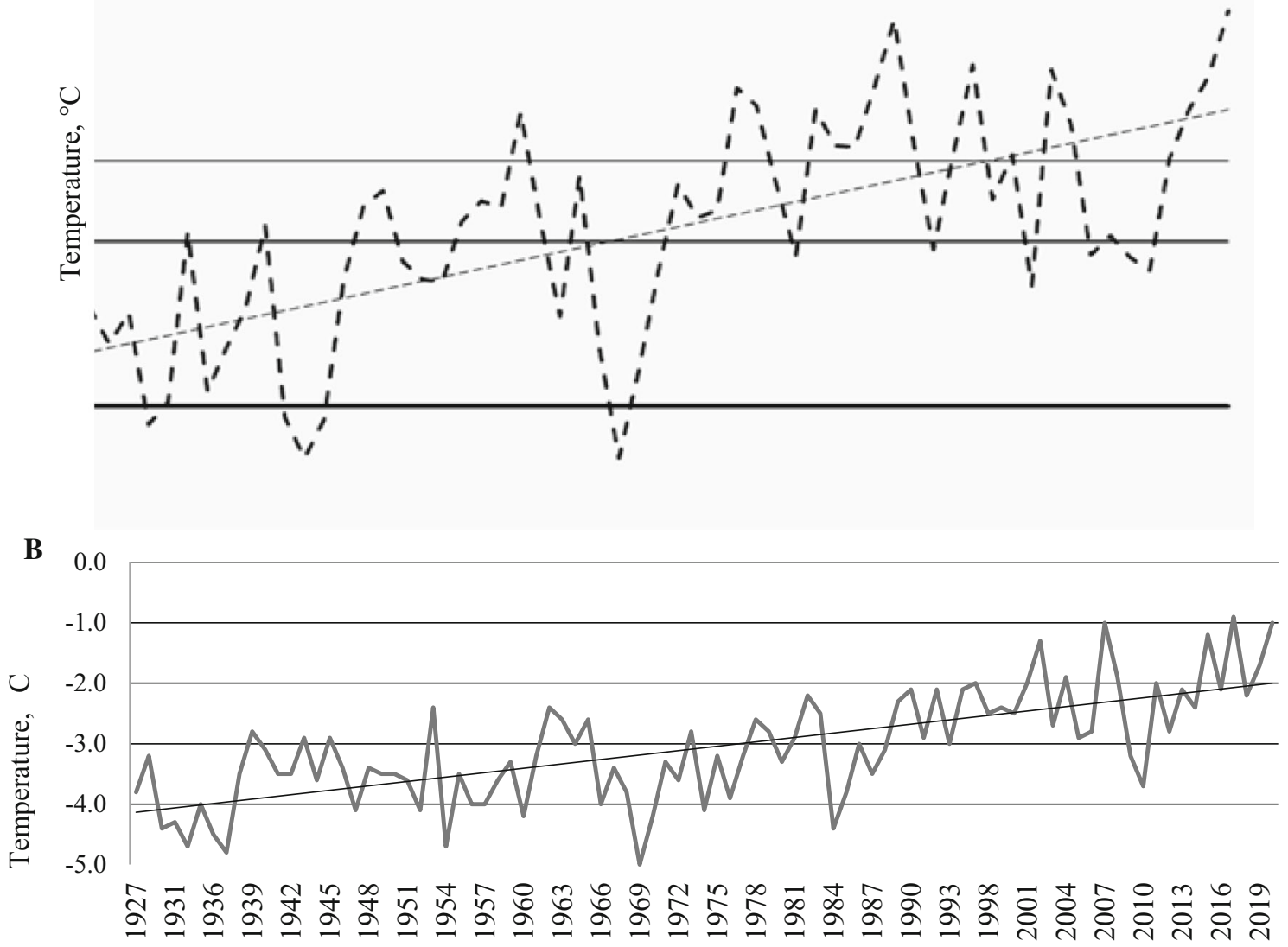

$\mathbf{C}$
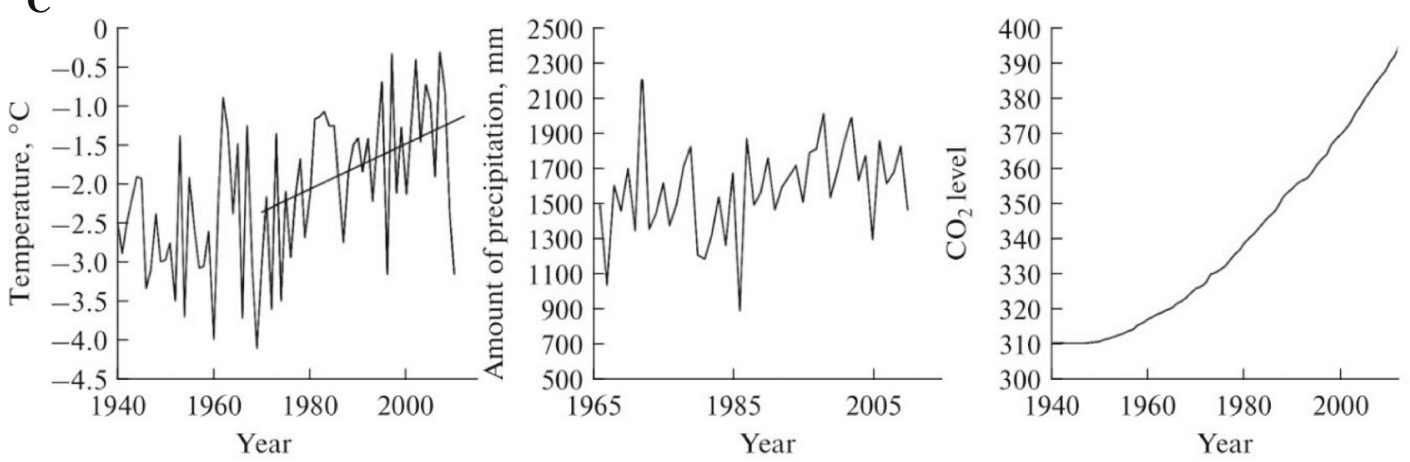

Fig. 3 A Dynamics of average annual air temperature recorded by the Meteorological Station “Kosh-Agach” (5000' $88^{\circ} 40^{\prime} 1759$ asl) (Sukhova and Zhuravleva 2017) about $25 \mathrm{~km}$ from the Aru mire within the South-Eastern Altai Mountains (SR2). B Dynamics of average annual air temperature recorded by the Meteorological Station "Olenya Rechka" $\left(52^{\circ} 80^{\prime} 93^{\circ} 23^{\prime}, 1394\right.$ asl) at the border of the mire at the Ergaki range within the West Sayan Mountains (SR3) (Information portal "Weather and Climate". Climate in Olenya rechka 2021). C Dynamics of average annual air temperature, precipitation and atmospheric $\mathrm{CO}_{2}$ level, recorded by the Meteorological Station "Nenastnaya" (N54 ${ }^{\circ} 45^{\prime}$ E88 ${ }^{\circ} 49^{\prime} 1186$ asl) (Sukhova and Zhuravleva 2017) about $35 \mathrm{~km}$ from the Krestovskye mires within the Kuznetsky Alatau Mountains (SR1)

Since the beginning of instrumental observations in 1927, temperature has increased at the Ergaki range (SR 3, Fig. 3B). The most humid region-the Kuznetsky Alatau Mountains (SR 1)-also demonstrates the trend of increasing annual air temperature since 1940 (Fig. 3C).
$\mathrm{CO}_{2}$ level increased also while the precipitation trend has changed insignificantly.

Considering the few micrometeorological data available (Sevastyanov 1998), we can assume that the zonal climate of vertical natural zones (belts) of the mountains in the 
south of Siberia is significantly transformed by mountain relief and by local conditions of the separate sites such as slope exposition, elevation, surrounding mountain tops, glaciers and proximity to snowbeds. In addition, orographic conditions cause sharp climatic contrasts (uneven precipitation, vertical climatic zonality, temperature inversions, development of mountain-valley winds) (Modina 1997).

\section{Holocene paludification, aridisation of climate and mire dynamics}

According to Tronov (1964), a decrease or increase in summer temperatures by $1^{\circ} \mathrm{C}$ affects the snow line as well as an increase or decrease in rainfall by $300 \mathrm{~mm}$. Today, mires in the mountains of South Siberia exist under progressing aridisation of climate (Kokorin 2011). The oldest peat-accumulating mires appeared here about 4500 to 5000 years ago, in the Holocene Climatic Optimum, when the environmental conditions were warm and wet enough to start peat accumulation (Muldiyarov and Lapshina 2000; Volkova et al. 2009). This was the period of paludification with lake formation and peatland development from the ponds. After that, the sub-boreal and subatlantic periods (the last 4500 years) were more or less a single stage in the development of Siberia in general. During this time, climate cooling and continentality increased, and the paludufication processes reached a grandiose scale (Nenasheva 2013). Most of the peatlands in this later stage are formed on land, replacing mixed deciduous and coniferous forests. Current conditions are not favorable for peat accumulation, especially in the most southern part of the Altai-Sayan Mountains - the arid South-Eastern Altai (within SR 2). The drying and shrinking of the mires, based on our visual observations while revisiting of some mire massifs during 15 years, are most evident in the arid southeastern part of the Altai Mountains, under conditions of current climate change.

\section{Permafrost degradation and active layer increase}

The permafrost of high mountain areas in the European Alps, Scandinavia, Canada, Mongolia, the Tien Shan and the Tibetan Plateau has warmed during recent decades (IPCC 2019) and some observations reveal ground-ice loss and permafrost degradation (Hock et al. 2019). Resulting increases of active-layer thickness in the European Alps (Christiansen et al. 2010), on the Tibetan Plateau (Wu et al. 2015), and in the Tien Shan (Liu et al. 2017) in steppe, meadow, and bedrock landscapes has occurred during the past few decades. Only in peatlands in Scandinavia (subarctic Sweden) was active layer thickness monitored (Åkerman and Johansson 2008). Here also, active layer thickness increased while permafrost in some of the sampled mires disappeared completely during the measurement period. In the Altai-Sayan Mountains, this important driver of climate-induced dynamics of mire ecosystems has not been studied yet, although we expect that the active layer thickness is increasing and will contribute to the increasing instability of the mire environment and habitats (Fig. 2).

Decadal-scale permafrost warming and degradation are driven by air temperature increase and are additionally affected by changes in snow cover, vegetation and soil moisture (Hock et al. 2019; Anisimov and Zimov 2020) (Fig. 2). Mires (including their integral components-the bryophytes) are permanently (or almost constantly) moist ecosystems but have a heat-insulating layer of peat. They are therefore good indicators of permafrost state and also play a large role in its conservation.

\section{Pollution}

The impact of pollution on mountain mires (in comparison to other mountain ecosystems) is expected to be intensified significantly due to pollutants that accumulate in the peat deposit as a result of filtration of water passing through the mires both vertically and laterally (Volkova et al. 2010) (Fig. 2). Although the consequences of such influences on the biota of the Altai-Sayan mountain mires are not known yet, there are several major sources of pollution. Residual local pollution of the top-soil with long-lived radionuclides is a result of nuclear tests at the Semipalatinsk test area (minimal distance to the SRs is about $250 \mathrm{~km}$ towards the east). Pollution by mining industry waste comes from neighbouring regions (non-ferrous metallurgy of Eastern Kazakhstan and the coal mining industry of the Kuznetsk Coal Basin) due to transboundary air transport of heavy metals and other pollutants in dust and aerosols. In addition, there is local mechanical and chemical pollution by fragments of rocket complexes and rocket propellant in the Altai Republic.

\section{Land use transformation}

Recent massive overgrazing by horses, cattle and sheep in the arid inter-mountain depressions of the Altai Mountains (SR 2) (Fig. 4), combined with permafrost thaw, has led to degradation and losses of mire ecosystems (Fig. 2). Cattle are pastured at the mires, causing the expansion of weed and steppe plant species (Cirsium esculentum (Siev.) C.A. Mey., species of Cobresia, Gentiana, Euphrasia, Rhinanthus, and many Asteraceae) into the mire ecosystems. Also, pasturing damages extensive mires located in the mouth of the Kan river near the Ust-Kan settlement (the Western Altai Mountains, SR 2) and the Aru mire (the SouthEastern Altai Mountains, SR 2) because of pollution by livestock waste which causes the eutrophication of the mire habitats and interrupts or even reverses the normal 

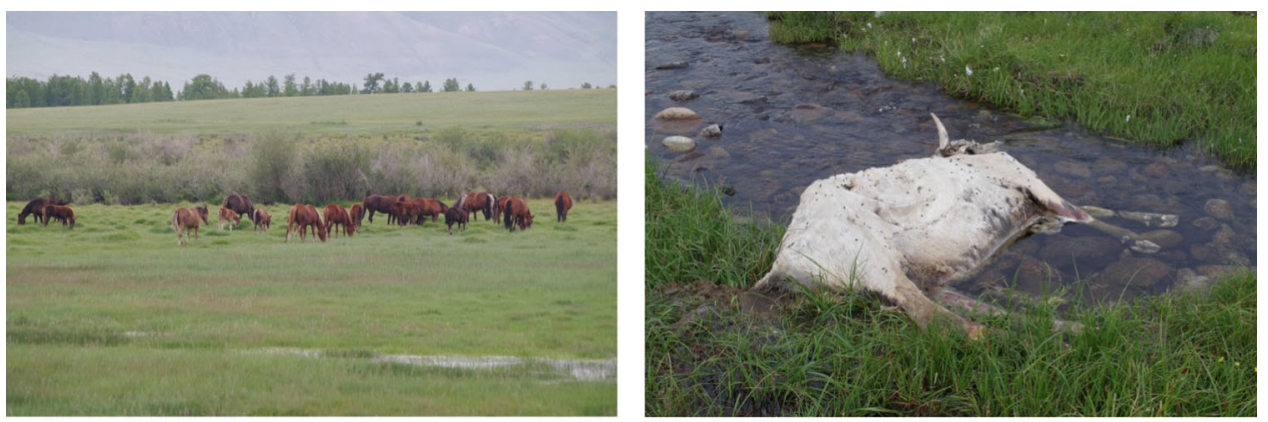

Fig. 4 Horses and dead cow at the Aru mire (the Altai Mountains, SR 2), indicating early stages of increased land use of the mires. Photos by I.V. Volkov, 2019

autogenic succession of the mire massif. The early changes of plant communities in the mires adjacent to the farms were more advanced than those of the mires at more remote areas. The same tendency is reported by Minayeva et al. (2016) in the adjacent mountains of Mongolia. Also, vegetation composition and structure of the arid region mires of Iran are influenced by heavy grazing by local domestic herds, particularly of cattle and sheep (Naqinezhad et al. 2019). In some cases, the establishment of the grazing culture had made the peatlands prone to degradation long before the recent intensification of peatland use (Joosten et al. 2008).

Additional land use pressures on the mires comes from natural resource use such as deforestation, berry gathering, as well hunting and poaching in protected natural territories and uncontrolled recreation such as intensification of tourism. For example, the number of tourists in the Altai Mountains increased from 0.4 million persons in 2001 to 2.2 million in 2019 (Robertus 2020), and this number has risen significantly due to the COVID-19 pandemic and incredible popularity of domestic tourism (Ganzhur 2021). Unorganized recreational tourists and the local population organize campsites, leave their garbage, damage and cut down tree stands and shrubs, that here, in the dry steppe and semi-desert areas, occupy only the wetlands. As human-induced pollution and drainage, along with grazing, are increasingly threatening small isolated wetlands, and considering that these ecosystems are usually ignored by national monitoring strategies (Moges et al. 2016), it is crucial to apply strict conservation policies to protect and restore them (Naqinezhad et al. 2019).

\section{Resulting ecosystem dynamics in the mountain mires}

\section{General ecosystem responses and interactions}

The consequences of these processes for the mires is peat mineralisation, changes in vegetation structure and changes in the composition of species and life forms (Fig. 2).
The balance of $\mathrm{CO}_{2}$ and other greenhouse gas emissions connected with increasing active layer thickness in the mountain mires are expected but have not been measured yet and need to be investigated in the future. Among the consequences is habitat loss for the very special basophilic mosses of calcareous mires, like, for example, Drepanocladus sendtneri (Schimp. ex H.Müll.) Warnst. Calcareous mires are a rare and vulnerable type of mire habitat, which can be found only in arid and semi-arid regions of the Altai Mountains both in Russia and in Mongolia.

Climate warming and aridisation will take a rare and protection-requiring plant community mentioned in the Green Book of Siberia (Sedel'nikov 1996) to the verge of extinction. This community is the crooked Elfin birch Betula tortuosa (Ledeb.) community which occupies mires and occurs only in the wettest and snowiest regions of the Altai-Sayan Mountains (namely the western macro-slope of Kuznetsky Alatau range, SR 1) where the eastern border of their natural distribution is situated. Although, such communities are widespread in sub-continental mountain regions of Scandinavia on peat-covered and rocky slopes of humid high mountains (Wielgolaski 2005), they are unique to South Siberia and are likely to be eliminated from there as a result of an upward shift of the upper boundary of the dark-needled mountain taiga under climate warming (Chlachula 2005). Since many other mountain mire plants and their communities are found in the Altai-Sayan Mountains at their distribution boundaries, they will potentially disappear in this region.

One of the most climate change-vulnerable types of mires in the mountains of Central Eurasia are permafrost (or frozen) mires. They represent disappearing habitats due to permafrost degradation. Among our investigated sites, frozen mires can be found only in the Altai Mountains (SR 2 ). They occupy large inter-mountain depressions, river valleys, flat tops and saddles of the mountains, with impermeable frozen soils acting as water beds. Permafrost can be continuous or intermittent, with taliks (islands of unfrozen ground in the permafrost area). Ice lenses occur in 
the ground and the soils of frozen mires can be mineral or peaty.

The largest areas of frozen mires are found in the Tuguruk Valley (Central Altai Mountains), in the Chuya Steppe (more precisely, the Kokorinsky Steppe and the Aru Mire) as well as in some valleys of the North-Chuysky Range (South-Eastern Altai), near the Tsagany Mountain on the northern spur of the Ilogo Range (Northern Altai Mountains) (Appendix S1).

\section{The specific case of the Aru mire massif}

The Aru mire (coordinates of the central part are $\mathrm{N} 50^{\circ} 01^{\prime} 38^{\prime \prime} \mathrm{E} 89^{\circ} 03^{\prime} 54^{\prime \prime}$ ) is located in the northeastern part of the Chuya steppe (the Altai Mountains) between the Talduair and Kuraisky ranges in the Kokoria River valley at an altitude of $1950 \mathrm{~m}$ above sea level. The approximate size of the mire is $8 \mathrm{~km}^{2}$. The Aru massif is a calcareous eutrophic mire (i.e. rich fen) covered by shrub-hummocky sedge-green moss (i.e. Bryales) vegetation, with patches of coniferous forest. The mire, located in a flat mountain valley, is surrounded by steppe vegetation (Fig. 5).

Localization of sedimentation of alluvium, permafrost processes (heaving, frost-cracking, underground ice, thermokarst, solifluction), springs and features of the relief create a wide variety of habitats within the mire, with six main habitat types physiognomically recognized (Appendix S1). The characteristic landscape features of the mire massif are outcrops of islands of the mineral bed inhabited by steppe plant communities.

Over 15-years, there have been pronounced changes of the vegetation of the Aru mire caused by overgrazing, permafrost degradation and consequent increases of topsoil moisture, active layer depth, and increased nutrients (mainly nitrogen) that stimulated autogenic mire succession. The border of the mire massif demonstrates the most significant changes (Fig. 6).

Between 2004 and 2019, the abundance of the moss populations and total coverage of the moss layer of the plant communities on the border between steppe and mire decreased (on average from 15 to $5 \%$ of the relevés' areas (Volkova and Volkov, unpubl.). In contrast, the herbs expanded very quickly. These processes are associated with the biological characteristics of mosses and higher plants as with the thawing of permafrost and faster decomposition: higher plant root systems are favored and mosses are displaced. The invading herb species are not characteristic mire plants and originate from the steppe phytocoenoses: they have dense growth forms, preventing moss secondary succession.

Permafrost degradation causes an ecological phenomenon we call "a drift of habitats". During climateinduced melting of the upper permafrost layer, the mire surface becomes much wetter than usual, and the thermokarst process causes a micro-relief inversion: hummocks and hollows replace each other. Former hollows, occupied by marsh arrowgrass (Triglochin palustris L.) and hooked scorpion-moss (Scorpidium scorpidioides (Hedw.) Limpr.) become hummocks, and the moss cover degrades with a decreased abundance of the hygrophilous hooked scorpionmoss (Fig. 7). At the same time, plant communities of former hummocks, dominated by the Altai sedge (Carex orbicularis ssp. altaica (Boot) Egor.), the tufted bulrush (Trichophorum cespitosum (L.) Hartm.) and Sendtner's drepanocladus moss (Drepanocladus sendtneri) are exposed to wetter conditions than before, and this moss cover also degrades, being replaced by hooked scorpionmoss. Consequently, the green mosses Scorpidium scorpidioides and Drepanocladus sendtneri are important indicators of this process analogous to hummock-hollow dynamics described for Sphagnum-dominated peatlands (Bogdanovskaya-Giennef 1936). As a regeneration cycle, this model was initiated by von Post and Sernander (1910), developed by Osvald (1923) and often described subsequently. In the mires of the Altai Mountains, we firstly describe this replacement process for the green moss mire and connect it with the thermokarst microtopography cycle, not with the biogenic factors such as an autogenic

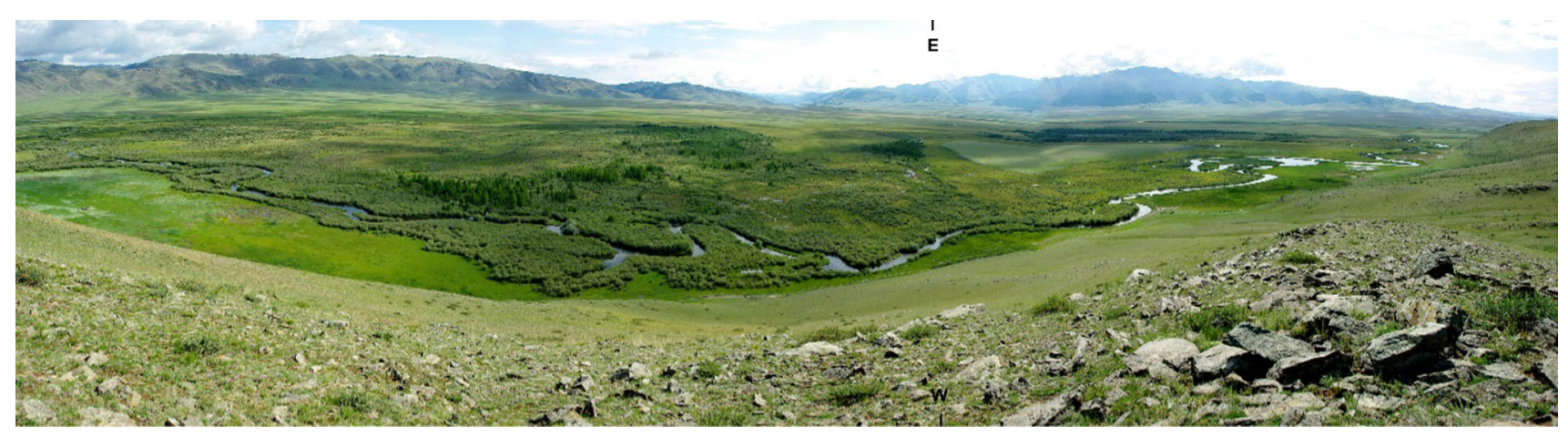

Fig. 5 Panoramic view of the Aru mire (the Altai Mountains, SR 2). Photo by I.V. Volkov, 2019 

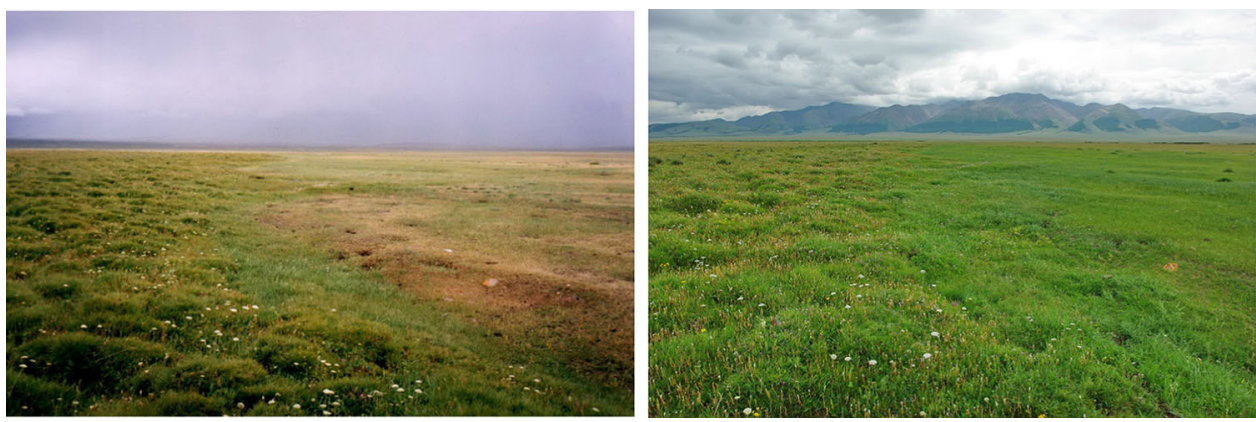

Fig. 6 The border between the Aru mire and surrounding steppe: left 2004 and right 2019 taken from the same place. By 2019, the former mire hollows near the border were occupied by grasses that are characteristic for the steppe vegetation. Photo by I.I. Volkova

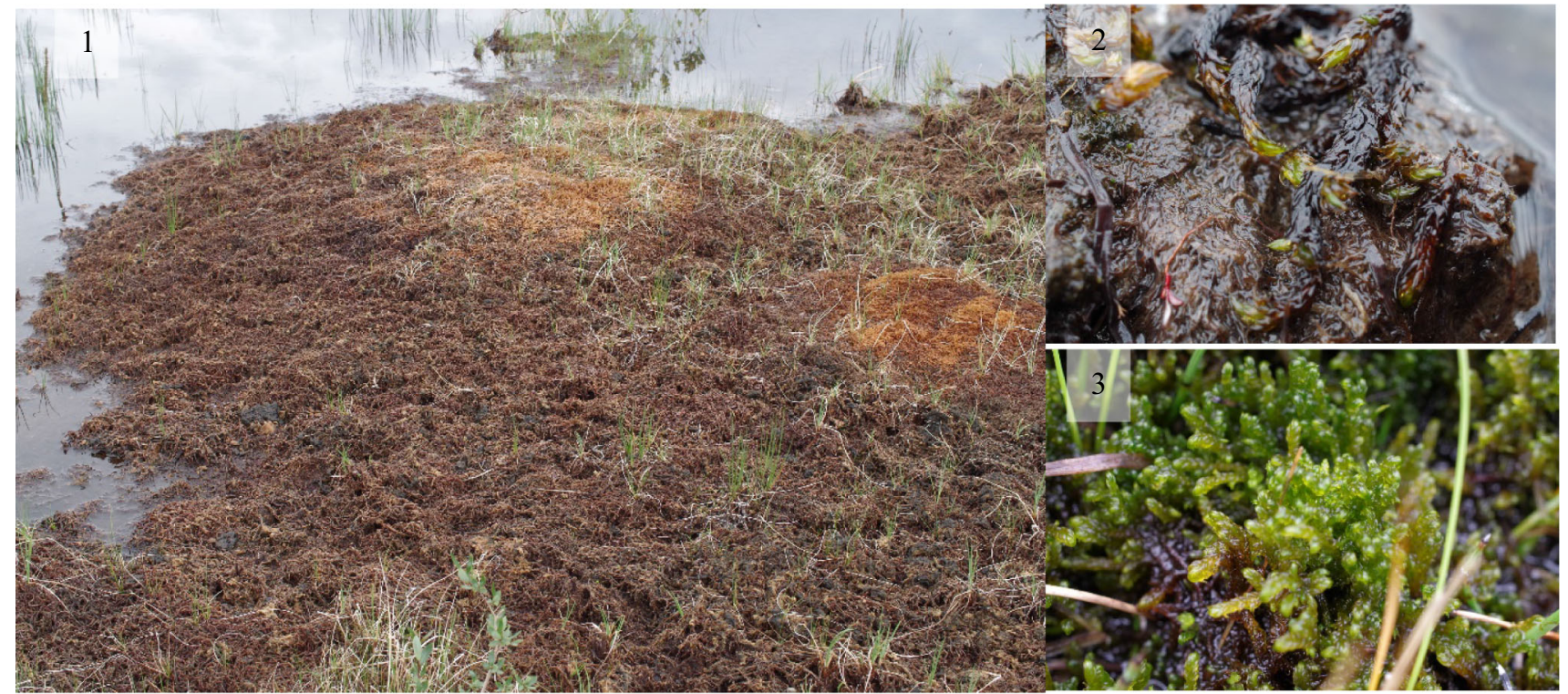

Fig. 7 Bryophytes on the Aru mire in the arid Southern Altai: (1) dynamics of the community of green mosses under permafrost degradation; (2) hooked scorpion-moss (Scorpidium scorpidioides), (3) Sendtner's drepanocladus moss (Drepanocladus sendtneri). Photos by I.V. Volkov, 2019

succession of the peatland development as described earlier by others. The development sequence is based on three visual observations: (1) populations of one moss species are overgrown by another; (2) plant remains on the top of the peat deposit reflect the replacement of one dominating population over another; (3) the Altai sedge actively invades into the former hollow plant communities.

Although the vegetation of the frozen Tsagany mountain mire in the Central Altai Mountains (Appendix S1) contrasts with the Aru mire, as it provides habitats for Sphagnum mosses that are not often found in the Altai Mountains, it too is changing. The hollows are dominated by Sphagna and the height of some mounds can reach $120 \mathrm{~cm}$ and the upper dry parts of mounds are covered by lichens. Complete replacement of the Sphagnum by Polyrichum strictum Brid., revealed by plant macrofossil analysis (Volkova, unpublished data), and increasing abundance of lichens indicate significant drying of the mound tops. Some of the mounds are replaced by ponds as a result of permafrost degradation. Consequently, characteristic mire species are disappearing and being replaced by generalist species that are more abundant and widespread in steppes, meadows and disturbed landscapes of the Altai Mountains (Appendix S1).

\section{$\beta$-diversity of bryophytes of the South-Siberian mountain mires}

Although there is a great variety of topological and ecological types of mires in the three observed regions, which are remote and $400-500 \mathrm{~km}$ away from each other, the floristic relationships among their bryophyta species, 
expressed by means of Sørensen's index (Appendix S2, Tables S4, S4a and S4b), revealed a high level of similarity. We are the first to describe the bryophytes for this regional partial flora of the mires, as well as reveale its taxonomical structure and the analysis of fidelity to mire habitats.

The highest similarity is revealed for Sphagna. Among the Sphagnum mosses of mountain mires of the AltaiSayan region, $65.5 \%$ of species have areas that cover all the longitudinal sectors of the Northern Hemisphere, but not beyond the Holarctic. The remaining $34.5 \%$ are species widely distributed in the Northern Hemisphere, but which also have a few locations in the extratropical regions of the Southern Hemisphere. Calculations of $\beta$-diversity, as the number of shared species and the Sørensen's Index, among the three survey regions revealed that Sphagnum floras of the Altai (SR2) and the West Sayan (SR3) are most similar and characterized by the lowest $\beta$-diversity (Appendix S2, Table S4b). The other two pairs of regions show a similar level of diversity. Sørensen's Indices are close to one ( $\sim 0.8)$ indicating that the $\beta$-diversity of Sphagna of the investigated three survey regions is in general low and confirms the similarity of the ecosystems surveyed and their common evolutionary history (Cazzolla Gatti 2016).

In contrast, the lists of mire hepatics significantly differ, and particularly between the Altai Mountains (SR2) and the West Sayan Mountains (SR3). A reduced similarity index of the flora of the liverworts and, to a lesser extent, the flora of green mosses affects the similarity index of the bryofloras as a whole, lowering it against the background of a high similarity of the flora of Sphagnum mosses.

\section{Rare and threatened bryophytes of the South-Siberian mountain mires}

Within the partial flora, consisting of 229 species in total, there is a high taxonomical diversity of bryophytes (Fig. 8; Appendix S2, S3, Tables S1, S2 and S3).

Some species are rare and endangered while new species have been recently recorded, two of which are related to new ecological niches resulting from increased grazing. For example, in the Altai and the Western Sayan Mountains many Sphagnum species are known only from the bogs situated at the tree line belt (i.e. S. lindbergii, $S$. jensenii, S. riparium, etc.) (Ignatov 1994). Some of bryophytes, like green mosses Pseudocalliergon trifarium (Web. et Mohr) Loeske, inhabiting mires on the Kuznetsky Alatau (SR 1), or hepatic Cephalozia connivens (Dicks.) Lindb. on the mires of the Ergaki Range (SR 3), are included in the regional Red Data Books as endangered species. Five species of mosses-Drepanocladus longifolius (Mitt.) Broth. ex Paris, Mnium spinosum (Voit) Schwaegr, Splachnum ampullaceum Hedw., Splachnum luteum Hedw. and Sphagnum subfulvum Sjörs were reported in the Altai-Sayan Mountains for the first time (Volkova et al. 2009). Two of these mosses, firstly discovered in the mires of the Altai Mountains, are inhabitants of a very special substrate-animals' excrements. Their appearance is connected with increasing cattle, horses and sheep grazing on the degrading mire areas. By forming additional ecological niches to the mire ecosystems, they facilitate invasions of species alien to the mires.

\section{DISCUSSION AND CONCLUSIONS}

Our earlier observations of the different directions of the development of wetlands in Western Siberia, from rapidly progressing paludification in the plains of the taiga zone and melting of frozen forest-tundra soils to the rapid degradation of wetlands in the arid South-Eastern Altai Mountains, generally correspond to the Voeikov law (1884): when temperatures begin to increase in the north, the climate becomes more arid in more southern regions. This law is especially pronounced in the mountains, where mire massifs are often relatively small in area, strongly dependent on the surrounding climatic situation and sensitive to anthropogenic impact (Volkova et al. 2009), unlike the vast peatlands of the West Siberian Plain, which have a much larger "buffering capacity" and autonomy in terms of exposure to climate fluctuations and other external influences. Changes in the environment of the mountain regions of the south of Western Siberia are inferred in the dynamics of the various components and characteristics of unique, but poorly studied, mire and peatland ecosystems (Fig. 2). This is especially true of mire massifs with permafrost in the peat deposits, since in this case, changes in ecosystems are associated not only directly with the climate, but also with climate-dependent dynamics of processes connected with permafrost degradation.

During climate change, we have observed (but not measured) many characteristics and parameters of mountain mires and peatlands that are changing, for example, the area of mire massifs, the hydrographic network, the water content and its chemical composition, the degree of permafrost development, the rate of accumulation of peat and its composition, etc. The vegetation is also changing: some communities and species are replaced by others and species alien to the mire ecosystems are expanding from the surrounding landscapes.

The mire bryofloras of the three survey regions are approximately the same size, aggregated in almost equal areas and demonstrate rather high homogeneity, especially within the Sphagnum mosses, the most typical group of bryophytes for the mire habitats. The three bryofloras together represent a partial flora of mountain mires of the 
A

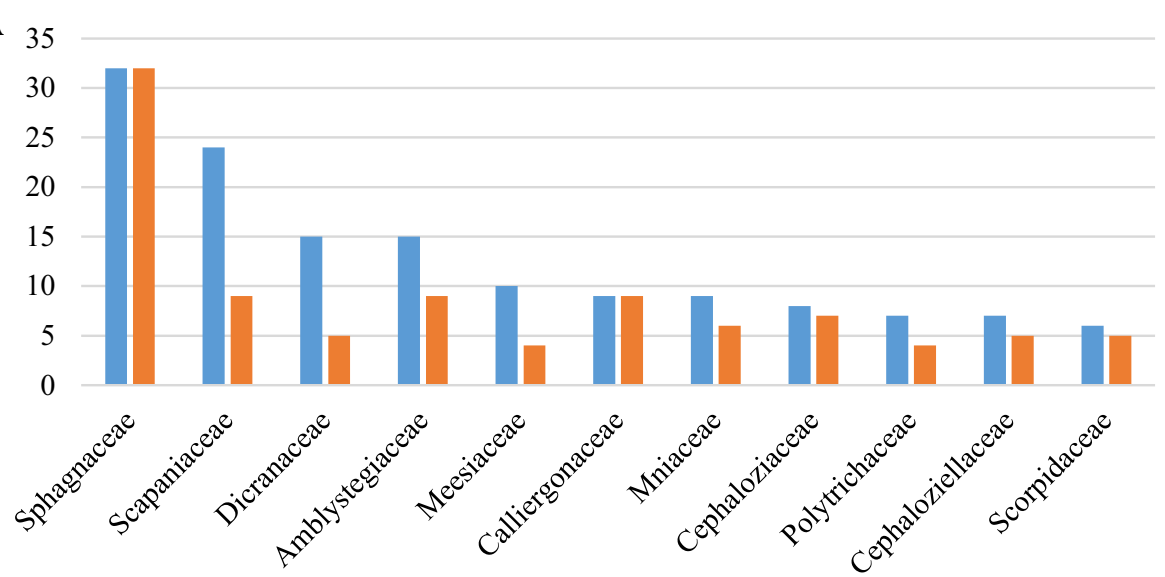

- Number of species in the family - Total investigated mountain mires bryoflora

Number of species in the family - Core of the mountain mires bryoflora

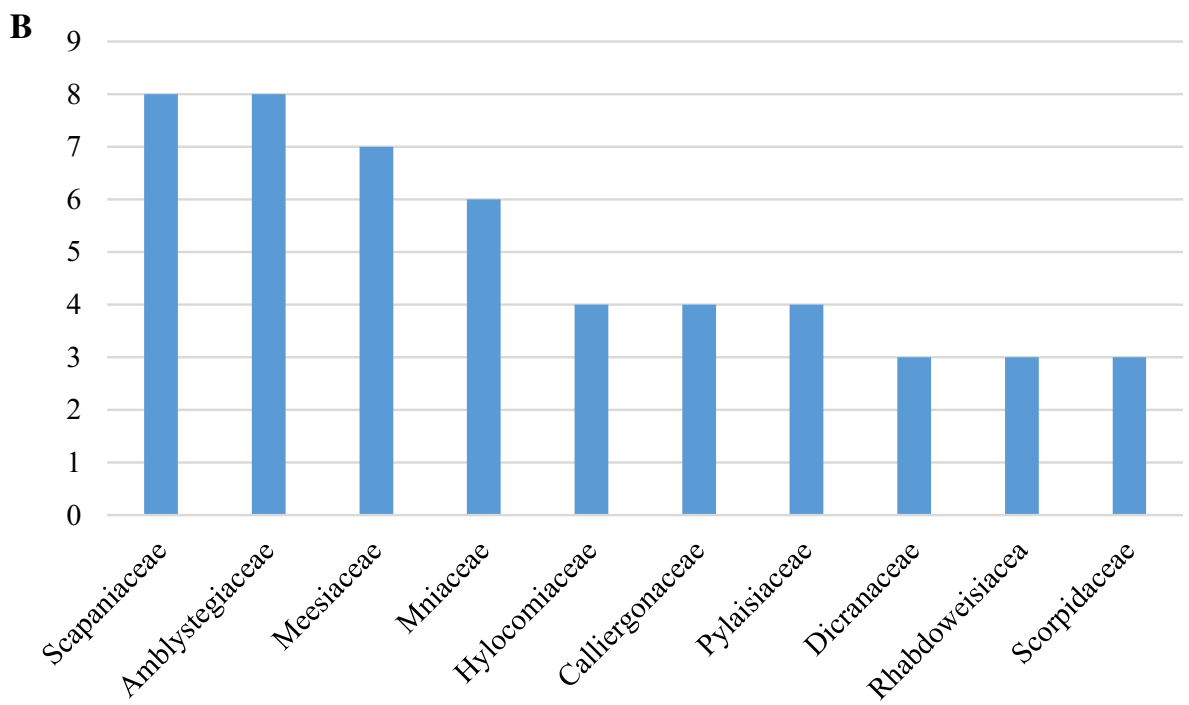

$\mathbf{C}_{35}$

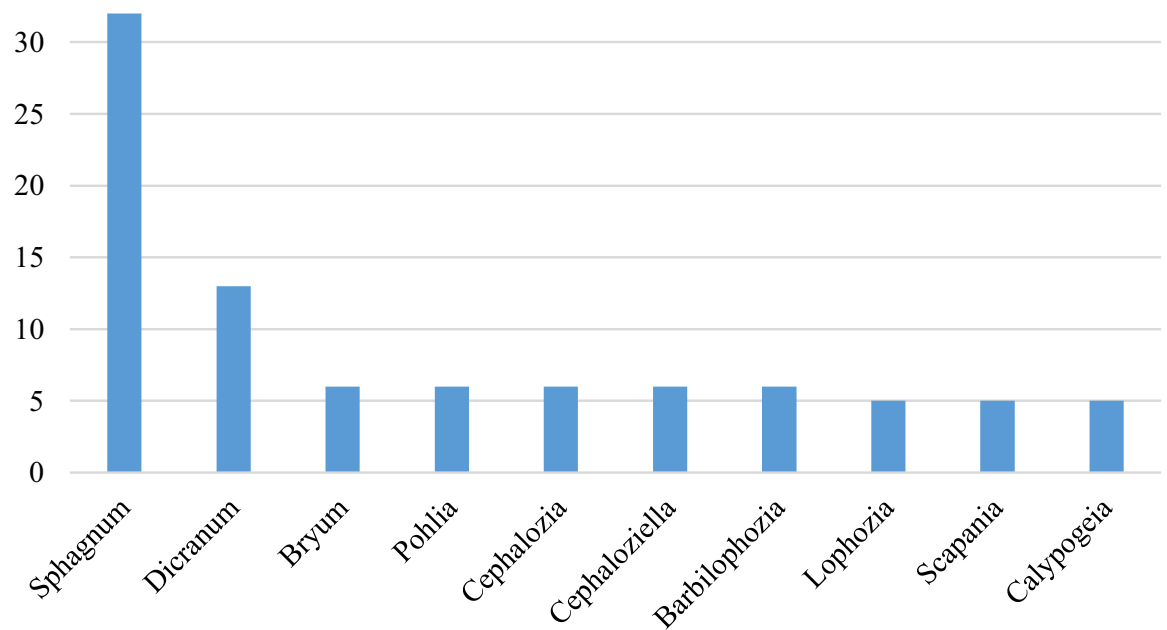

Fig. 8 Taxonomical structure of mire bryoflora of the Altai-Sayan Mountains. A Number of species of the richest families (family species range (spectra)) separately for the total investigated bryoflora and for the core of this bryoflora. B Number of genera of the richest families (family genera range (spectra)). C Number of species of the richest genera (genera-species range (spectra)) 
South Siberia. Within this partial flora, there is a high bryophyte species diversity. Some of them are rare and endangered species while new species have been recently recorded, two of which are related to increasing ecological niches resulting from increased grazing.

The important mountain mire habitats and their bryofloras are experiencing impacts of overgrazing, waste pollution from industry and agriculture, mires drainage, peat production and other economic activities. We expect these impacts to lead to further biodiversity change caused by the disappearance of plant and animal species specific to mires, some of which are endemic, rare or threatened, and the introduction of alien species. We also expect changes in the seasonal fluctuation of water level in the rivers and the disappearance of some small rivers and streams that could lead to the loss of the unique South-Siberian mountain mire landscapes. Such loss would generally impact the Altai Mountains, a location of the mountain permafrost zone in Siberia and a global hotspot of biodiversity and a World Heritage site (Bertzky et al. 2013).

Despite extensive fieldwork over 25 years, we still know little about the dynamics of changes in the ecosystems of the mountains of southern Siberia. It is very difficult to establish monitoring studies in this remote area due to its vast extent and the difficulties in accessing sites. Also, although remote sensing techniques can provide information on the changing extents and productivity of the mires, detailed in situ measurements are needed to record biodiversity changes.

Our study has highlighted the importance and vulnerability to change of the unique mountain mires of the remote and inaccessible Altai-Sayan mountain region providing a base-line for future studies. For future research, we recommend:

- Quantifying the changes in environment: climate, dynamics of permafrost and hydrology, land use and pollution.

- Quantifying the large scale dynamics of the mires: area, patterning and productivity from remote sensing.

- Quantifying the changes in biodiversity and species niche preferences.

- Predicting future changes by experimentally relating the changes in ecosystems and species occurrence/ abundance/location to external environmental change drivers.

- Designing and implementing conservation methods for the mires based on the scientific knowledge gained above.

Acknowledgements The authors are grateful for support from the Tomsk State University Competitiveness Improvement Programme. They also would like to thank the European Union's Horizon 2020
INTERACT project (grant agreement 730938), INTERACT Aktru Research Station (https://eu-interact.org/field-sites/aktru-researchstation/) and the research infrastructure "System of experimental stations located along the latitudinal gradient" for fruitful cooperation (http://ckp-rf.ru/usu/586718/; http://www.secnet.online/megaustanovkaru.html). Irina Volkova and Igor Volkov express their gratitude to the Russian Science Foundation (grant № 20-67-46018). Anastasia Volkova thanks project NIR № 0264-2019-0010. This article could not have seen the light of day without constant kind technical assistance and moral support of Olga Morozova (Shaduyko), the Guest Editor of the Siberian Environmental Change Ambio Special Issue.

\section{REFERENCES}

Åkerman, H.J., and M. Johansson. 2008. Thawing permafrost and thicker active layers in sub-arctic Sweden. Permafrost and Periglacial Processes 19: 279-292.

Anisimov, O., and S. Zimov. 2020. Thawing permafrost and methane emission in Siberia: Synthesis of observations, reanalysis, and predictive modeling. Ambio. https://doi.org/10.1007/s13280020-01392-y.

Bengtsson, F., G. Granath, and H. Rydin. 2016. Photosynthesis, growth, and decay traits in Sphagnum: A multispecies comparison. Ecology and Evolution 6: 3325-3341.

Bertzky, B., Y. Shi, A. Hughes, B. Engels, M.K. Ali, and T. Badman. 2013. Terrestrial Biodiversity and the World Heritage List: Identifying broad gaps and potential candidate sites for inclusion in the natural World Heritage network. Cambridge: IUCN, Gland, Switzerland and UNEP-WCMC.

Bezuglova, N.N., G.S. Zinchenko, N.S. Malygina, T.S. Papina, and T.V. Barlyaeva. 2012. Response of high-mountain Altai thermal regime to climate global warming of recent decades. Theoretical and Applied Climatology 110: 595-605. https://doi.org/10.1007/ s00704-012-0710-2.

Bogdanovskaya-Giennef, I.D. 1936. Formation and development of ridges and hollows in the mires. Soviet Botany 6: 35-52. (in Russian).

Bokhorst, S.F., J.W. Bjerke, H. Tømmervik, T.V. Callaghan, and G.K. Phoenix. 2009. Winter warming events damage sub-Arctic vegetation: Consistent evidence from an experimental manipulation and a natural event. Journal of Ecology 97: 1408-1415. https://doi.org/10.1111/j.1365-2745.2009.01554.x.

Botch, M.S. 1972. On the application of indicator properties of mire vegetation in determining the type of nutrient supply. In Basic principles for studying mire biogeocoenoses, ed. N.I. Pyavchenko. Leningrad: Nauka. (in Russian).

Bourgeois, I., L. Cammaert, C. Massart, J.H. Mikkelsen, and W. Van Heule. 2000. Ancient Nomads of the Altai Mountains. BelgianRussian Multidisciplinary Archaeological Research on the Scytho-Siberian Culture. Brussels: Royal Museums of Art and History.

Bragazza, L. 2006. A decade of plant species changes on a mire in the Italian Alps: Vegetation-controlled or climate-driven mechanisms? Climatic Change 77: 415-429. https://doi.org/10.1007/ s10584-005-9034-x.

Braun-Blanquet, J. 1964. Plant sociology. Wien. 865 p. (in German).

Brown, R.J.E. 1967. Permafrost in Canada. Geological Survey of Canada Map 1246a and Division of Building Research Map NRC-9769. National Research Council of Canada: Ottawa.

Callaghan, T.V., O.M. Shaduyko and S.N. Kirpotin 2021. Siberian Environmental Change, Ambio 50 (Special Issue).

Cazzolla Gatti, R. 2016. The fractal nature of the latitudinal biodiversity gradient. Biologia 71: 669-672. 
Chlachula, J. 2005. Biodiversity Protection of Southern Altai in the Context of Contemporary Environmental Transformations and Sustainable Development, 95p. Irbis, Staré Město: Final Report on Field Study.

Christiansen, H.H., B. Etzelmüller, K. Isaksen, H. Juliussen, H. Farbrot, O. Humlum, M. Johansson, T. Ingeman-Nielsen, et al. 2010. The thermal state of permafrost in the nordic area during the international polar year 2007-2009. Permafrost and Periglacial Processes 21: 156-181. https://doi.org/10.1002/ppp. 687.

Climate in Olenya rechka. Reference and information portal "Weather and Climate". Retrieved 10 February, 2021, from http://www.pogodaiklimat.ru/history/29974.htm.

Clymo, R.S., and P.M. Hayward. 1982. The Ecology of Sphagnum. London: Chapman and Hall Ltd.

Dobricic, S., S. Russo, L. Pozzoli, J. Wilson, and E. Vignati. 2020. Increasing occurrence of heat waves in the terrestrial Arctic. Environmental Research Letters 15: https://doi.org/10.1088/ 1748-9326/ab6398.

Elina, G.A., O.L. Kuznetsov, and A.I. Maksimov. 1984. The structural and functional organisation and dynamics of Karelian mire ecosystems. Lengingrad: Nauka. (in Russian).

Ganzhur E. 2021. Everything is crammed: How Altai ceased to be the Russian Iceland and how much is the rest now here. Retrieved 23 May, 2021, from https://www.forbes.ru/biznes/406295-zabitovse-kak-altay-perestal-byt-russkoy-islandiey-i-skolko-teperzdes-stoit-otdyh) (in Russian).

Golitsyn, G.S., and A.A. Vasiliev. 2019. Climate change and its impact on the frequency of extreme hydrometeorological occurrence. Meteorology and hydrology 11: 9-12. (in Russian).

Hanski, I. 2015. The shrinking world: Ecological consequences of habitat loss, 2nd ed. Oldendorf/Lune: International Ecology Institute.

Harris, C. 2018. Data shows Sweden's wildfire problem is unusual. Euronews 20 July 2018. Retrieved 11 August 2020, from https:// www.euronews.com/2018/07/20/this-chart-explains-howunusual-sweden-s-wildfire-problem-is.

Hock, R., G. Rasul, C. Adler, B. Cáceres, S. Gruber, Y. Hirabayashi, M. Jackson, A. Kääb, et al. 2019. High Mountain Areas. In: IPCC Special Report on the Ocean and Cryosphere in a Changing Climate, ed. H.-O. Pörtner, D.C. Roberts, V. MassonDelmotte, P. Zhai, M. Tignor, E. Poloczanska, K. Mintenbeck, A. Alegría, et al. in press.

Ignatov, M.S. 1994. Bryophytes of the Altai Mountains. I. Study area and history of its bryological exploration. Arctoa 3: 13-27.

Ignatov, M.S., O.M. Afonina, E.A. Ignatova, et al. 2006. Check-list of mosses of East Europe and North Asia. Arctoa 15: 1-130.

IPCC. 2014. Climate change 2014: synthesis report. In: Contribution of Working Groups I, II and III to the Fifth Assessment Report of the Intergovernmental Panel on Climate Change, ed. R. Pachauri and L. Meyer. Geneva: IPCC (ISBN: 978-92- 9169-143-2).

IPCC. 2019. IPCC Special Report on the Ocean and Cryosphere in a Changing Climate, ed. H.-O. Pörtner, D.C. Roberts, V. MassonDelmotte, P. Zhai, M. Tignor, E. Poloczanska, K. Mintenbeck, A. Alegría et al. in press

Ivanov, K.E. 1981. Water movement in mirelands. Translated by Thomson, A. and Ingram, H.A.P. In Ivanov, K.E. 1975. Vodoobmen $v$ bolotnykn landshaftakh. London: Academic Press.

Joosten, H. 1993. Thinking like a bog: Hydrological selfregulation of raised bogs and its importance for rewetting and restoration. Telma 23: 95-115. (in German).

Joosten, H., and D. Clarke. 2002. Wise use of mires and peatlands: Background and principles including a framework for decisionmaking, 304. Saarijärvi: International Mire Conservation Group/ International Peat Society.
Joosten, H., A. Haberl and M. Schumann. 2008. Degradation and restoration of peatlands on the Tibetan Plateau. Peatlands International 2008/1.

Kharlamova, N.F. and O.V. Ostanin. 2012. Review of up-to-date thermal regime of the Altai-Sayan ecoregion and possible prognosis. The News of Altai State University 3-1: 147-152 (in Russian, English summary).

Kharlamova, N.F., M.G. Sukhova, and J. Chlachula. 2019. Present climate developments in Southern Siberia (1963-2017 years). IOP Conference Series: Earth and Environmental Science 400: https://doi.org/10.1088/1755-1315/400/1/012008.

Kirpotin, S., O. Antoshkina, A. Berezin, S. Elshehawi, A. Feurdean, E. Lapshina, O. Pokrovsky, A. Peregon, et al. 2021. Great Vasyugan Mire: How the world's largest peatland helps addressing the world's largest problems. Ambio. https://doi.org/ 10.1007/s13280-021-01520-2.

Kirpotin, S., A. Berezin, V. Bazanov, Y. Polishchuk, S. Vorobiov, N. Mironycheva-Tokoreva, N. Kosykh, I. Volkova, et al. 2009. Western Siberia wetlands as indicator and regulator of climate change on the global scale. International Journal of Environmental Studies 66: 409-421.

Kokorin, A.O. (ed.). 2011. Assessment Report: Climate change and its impact on ecosystems, population and economy of the Russian portion of the Altai-Sayan Ecoregion. Moscow: WWF Russia.

Körner, C. 2004. Mountain biodiversity, its causes and function. Ambio 13: 11-17.

Kuznetsov, O.L. 1991. Ecological-floristic classification of sphagnum communities of bogs. In: Methods of research of mire ecosystems of the taiga zone. Lengingrad: Nauka (in Russian).

Lang, S.I., J.H.C. Cornelissen, G.R. Shaver, M. Ahrens, T.V. Callaghan, U. Molau, C.J.F. Ter Braak, A. Hölzer, and R. Aerts. 2012. Arctic warming on two continents has consistent negative effects on lichen diversity and mixed effects on bryophyte diversity. Global Change Biology 18: 1096-1107.

Lapshina, E.D., and A.I. Maksimov. 2014. Sphagnum tenellum (Sphagnaceae, Bryophyta) in West Siberia. Arctoa 23: 70-79. https://doi.org/10.15298/arctoa.23.08.

Lett, S., I. Jónsdóttir, A. Becker-Scarpitta, C. Christiansen, H. During, F. Ekelund, G. Henry, S. Lang et al. In review. Bryophyte functional groups in tundra ecosystems. Arctic Science.

Liu, G., L. Zhao, R. Li, T. Wu, K. Jiao, and C. Ping. 2017. Permafrost warming in the context of step-wise climate change in the Tien Shan Mountains, China. Permafrost and Periglacial Processes 28: 130-139. https://doi.org/10.1002/ppp.1885.

Maksimov, A.I. 2015. The review of Sphagnaceae (Bryophyta) in Russia, results and study perspectives. Mires of Northern Europe: biodiversity, dynamics, management. International Symposium, Petrozavodsk, Russia, 52-53 (in Russian).

Minayeva, T., A. Sirin and C. Dugarjav. 2016. Highland Peatlands of Mongolia. In: The Wetland Book, ed. C. Finlayson, G. Milton, R. Prentice, N. Davidson. Dordrecht: Springer. https://doi.org/10. 1007/978-94-007-6173-5_108-1.

Modina, T.D. 1997. Climates of Altai Republic (in Russian).

Moges, A., A. Beyene, A. Ambelu, S.T. Mereta, L. Triest, and E. Kelbessa. 2016. Plant species composition and diversity in wetlands under forest, agriculture and urban land uses. Aquatic Botany 138: 9-15.

Mueller-Dombois, D., and H. Ellenberg. 1974. Aims and methods of vegetation ecology. New York: Wiley \& Sons.

Muldiyarov, E.Y., and E.D. Lapshina. 2000. Study of the Kuznetsk Alatau Swamps. Sibirsky Ecologichesky Zhurnal 7: 645-652. (in Russian, English summary).

Naqinezhad, A., E. Ramezani, A.H. Khalili, and H. Joosten. 2019. Habitat and floristic peculiarities of an isolated mountain mire in the Hyrcanian region of northern Iran: A harbour for rare and 
endangered plant species. Mires and Peat 24, Article 21: 1-22. https://doi.org/10.19189/MaP.2017.OMB.321.

Nenasheva, G.I. 2013. Vegetation and climate of intermontane depressions of Central Altai in the Holocene. Barnaul: Altai State University (in Russian).

Osvald, H. 1923. The vegetation of the Komosse raised bog. Svenska Växtsociologiska Sällskapets Handlingar 1: 1-436. Uppsala (in German).

Parish, F., A. Sirin, D.Charman, H. Joosten, T. Minayeva, M. Silvius, and L. Stringer (eds.) 2008. Assessment on Peatlands, Biodiversity and Climate Change: Main Report. Global Environment Centre, Kuala Lumpur and Wetlands International, Wageningen.Peat Dictionary. 1984. Helsinki: International Pet Society. 595 p. (Russian-English-German-Finnish-Swedish).

Pitcairn, C., D. Fowler, I. Leith, L. Sheppard, S. Tang, M. Sutton, and D. Famulari. 2006. Diagnostic indicators of elevated nitrogen deposition. Environmental Pollution 144: 941-950. https://doi. org/10.1016/j.envpol.2006.01.049.

Ponomarev, E.I., E.G. Shvetsov, and V.I. Kharuk. 2016. Wildfire occurrence in forests of the Altai-Sayan region under current climate changes. Contemporary Problems of Ecology 9: 29-36. https://doi.org/10.1134/S199542551601011X.

Poplavskaya, G.N. 1924. Experience of phytocoenotic analysis of vegetation of virgin reserved steppe Askania-Nova. Journal of Russian Botanical Society 9: 125-146. (in Russian).

Potemkin, A.D. and E.V. Sofronova. 2009. Liverworts and hornworts of Russia. St. Petersburg-Yakutsk: Boston-Spectr.

Robertus, Yu.V. (ed.) 2020. Report on the state and protection of the environment of the Altai Republic in 2019 (in Russian). Retrieved 31 August, 2020, from http://ekologia-ra.ru/ publikaczii-doklady/.

Rogora, M., L. Frate, M.L. Carranza, M. Freppaz, A. Stanisci, I. Bertani, R. Bottarin, A. Brambilla, et al. 2018. Assessment of climate change effects on mountain ecosystems through a crosssite analysis in the Alps and Apennines. Science of the Total Environment 624: 1429-1442. https://doi.org/10.1016/j. scitotenv.2017.12.155

Russo, S., A. Dosio, R.G. Graverson, J. Sillmann, H. Carrao, M.B. Bunbar, A. Singleton, P. Montagna, et al. 2014. Magnitude of extreme heat waves in present climate and their projection in a warming world. Journal of Geophysical Research: Atmospheres 119: 12500-12512. https://doi.org/10.1002/2014JD022098.

Russo, S., J. Sillmann, and E.M. Fischer. 2015. Top ten European heatwaves since 1950 and their occurrence in the coming decades. Environmental Research Letters 10: https://doi.org/10. 1088/1748-9326/10/12/124003.

Sedel'nikov, V.P. 1996. Crooked Elfin birch Betula tortuosa (Ledeb.) woodland. In Green Book of Siberia: rare and in need of protection plant communities, ed. 337-339. Novosibirsk: Science, Siberian Publishing Company Russian Academy of Science (in Russian).

Seneviratne, S.I., N. Nicholls, D. Easterling, C.M. Goodess, S. Kanae, J. Kossin, Y. Luo, J. Marengo, et al. 2012. Changes in climate extremes and their impacts on the natural physical environment. In Managing the Risks of Extreme Events and Disasters to Advance Climate Change Adaptation. A Special Report of Working Groups I and II of the Intergovernmental Panel on Climate Change (IPCC), ed. C.B. Field, V. Barros, T.F. Stocker, D. Qin, D.J. Dokken, K.L. Ebi, M.D. Mastrandrea, K.J. Mach et al., 109-230. Cambridge University Press, Cambridge, UK, and New York, NY, USA.

Sevastyanov, V.V. 1998. Climate of alpine areas of the Altai and Sayan mountains. Tomsk: Publishing house of Tomsk University. (in Russian).
Shpin, P.S. 1980. Glaciation of the Kuznetsky Alatau Mountains. Moscow: Nauka. (in Russian).

Sokolov, A.A., N.A. Sokolova, R.A. Ims, L. Brucker, and D. Ehrich. 2016. Emergent rainy winter warm spells may promote boreal predator expansion into the Arctic. Arctic 69: 121-129. https:// doi.org/10.14430/arctic4559.

Steinbauer, M.J., J. Grytnes, G. Jurasinski, A. Kulonen, J. Lenoir, H. Pauli, C. Rixen, M. Winkler, et al. 2018. Accelerated increase in plant species richness on mountain summits is linked to warming. Nature 556: 231-234. https://doi.org/10.1038/ s41586-018-0005-6.

Succow, M., and H. Joosten (eds). 2001. Landscape ecology of mires. Stuttgart: Schweizerbart'sche Verlagsbuchhandlung (in German).

Sukachev, V.N. 1915. Mires, their formation, development and properties. Moscow: GEOS Publication. (in Russian).

Sukhova, M.G., and O.V. Zhuravleva. 2017. Dynamics of changes in air temperature and precipitation in the Chui basin. News of higher educational institutions. North Caucasus region. Natural Sciences 1: 124-129. (in Russian).

Tronov, M.V. 1964. On some geographic characteristics of climate in high mountain territory. Glaciology of Altai 3: 12-51. (in Russian).

Vergel, K., I. Zinicovscaia, N. Yushin, and S. Gundorina. 2020. Assessment of atmospheric deposition in Central Russia using moss biomonitors, neutron activation analysis and GIS technologies. Journal of Radioanalytical and Nuclear Chemistry 325: 807-816. https://doi.org/10.1007/s10967-020-07234-1.

Voeikov, A.I. 1884. The climates of the globe, especially Russia (in Russian).

Voiland, A. 2020. Heat and fire scorches Siberia. NASA Earth Observatory. Retrieved 10 February, 2021, from https:// earthobservatory.nasa.gov/images/146879/heat-and-firescorches-siberia.

Volkova, I.I., K.S. Baikov, and A.I. Syso. 2010. Kuznetsk Alatau Mires as Filters for Natural Waters. Contemporary Problems of Ecology 3: 265-271. https://doi.org/10.1134/ S1995425510030021.

Volkova, I.I., I.V. Volkov, and A.O. Kuznetsova. 2009. Mountain mires of South Siberia: Biological diversity and environmental functions. International Journal of Environmental Studies 66: 465-472.

Von Post, L., and R. Sernander. 1910. Plant physiognomic studies on peat bogs in Narke. Stockholm: Norstedt. (in German).

Wielgolaski, F.E. (ed.). 2005. Plant ecology, herbivory, and human impact in Nordic mountain birch forests. Berlin: Springer.

Wu, Q., Y. Hou, H. Yun, and Y. Liu. 2015. Changes in active-layer thickness and near-surface permafrost between 2002 and 2012 in alpine ecosystems, Qinghai-Xizang (Tibet) Plateau, China. Global and Planetary Change 124: 149-155. https://doi.org/10. 1016/j.gloplacha.2014.09.002.

Yurtsev, B.A. 1982. Flora as a natural system. Bulletin of Moscow Society of Naturalists Biological series 87: 3-22. (in Russian).

Yurtsev, B.A., and V.V. Petrovsky. 1971. About indication importance of the floristic complexes on the North-East USSR. In Theoretical problems of phyto-indication, 15-31. Leningrad: Nauka (in Russian).

Zheleznyak, M.N., M.M. Shatz, S.I. Serikov, R.G. Sysoliatin, Yu.B. Skachkov, and V.I. Zhizhin. 2020. Altitudinal geotemperature zonation in Central Altai. Earth's Cryosphere, XXIV: 16-21. https://doi.org/10.21782/ec2541-9994-2020-3(16-21).

Zhenlin, Y., M.T. Sykes, E. Hanna, and T.V. Callaghan. 2012. Linking fine-scale sub-arctic vegetation distribution in complex topography with surface-air-temperature modelled at 50-m 
resolution. Ambio 41: 292-302. https://doi.org/10.1007/s13280012-0307-0.

Zverev, A.A. 2007. Information technologies in studies of vegetation: Tutorial. Tomsk: TML-Press. 304 p. (in Russian).

Publisher's Note Springer Nature remains neutral with regard to jurisdictional claims in published maps and institutional affiliations.

\section{AUTHOR BIOGRAPHIES}

Irina I. Volkova $(\square)$ is Associate Professor of Department of Botany and Coordinator of Wetland Centre at Tomsk State University. Her research interests include mire science, bryology, geobotany, landscape ecology, nature wise use and conservation.

Address: Tomsk State University, 36 Lenina Pr, Tomsk, Russia 634050.

e-mail: volkovhome@yandex.ru

Terry V. Callaghan CMG is Professor of Arctic Ecology at Sheffield University, UK, and Professor of Botany at Tomsk State University, Russia. He is a founder of INTERACT - the international network of terrestrial research stations for research and monitoring in the Arctic and its scientific adviser. He is a co-founder and scientific director of the Siberian Environmental Change Network. His main interests include Arctic Ecology, Climate change, Traditional Indigenous Knowledge, Adaptation, Science Diplomacy.

Address: University of Sheffield, Alfred Denny Building, Western Bank, Sheffield S10 2TN, UK.

e-mail: terry_callaghan@btinternet.com
Igor V. Volkov is an Associate Professor of Department of General Biology and Methods of Teaching Biology at Tomsk State Pedagogical University. His research interests include plant ecology, adaptations to extreme environments, geobotany, landscape ecology, nature wise use and conservation.

Address: Tomsk State Pedagogical University, 60 Kievskaya St, Tomsk, Russia 634061.

e-mail: volkovhome2016@gmail.com

Natalia A. Chernova is Researcher of Department of Environmental Studies of Institute of Monitoring of Climatic and Ecological Systems of Russian Academy of Sciences. Her research interests include mire science, geobotany, bryology and landscape ecology.

Address: Institute of Monitoring of Climatic and Ecological Systems of Russian Academy of Sciences, Siberian Branch, 10/3 Akademichesky Pr, Tomsk, Russia 634021.

e-mail: naitina79@mail.ru

Anastasia I. Volkova is Junior Researcher of PaleoData Lab at Institute of Archaeology \& Ethnography, Russian Academy of Sciences. Her research interests is landscape dynamics, paleobotany and palynology.

Address: Institute of Archaeology \& Ethnography of Russian Academy of Sciences, Siberian Branch, 17 Lavrentieva Pr, Novosibirsk, Russia 630090

e-mail: justjustme@yandex.ru 